\section{Parameters of evaluation of zinc nutritional status: comparison between zinc hair rates and serum alkaline phosphatase in pre- scholars of the Municipality of João Pessoa, Paraíba}

\section{Parâmetros de avaliação do estado nutricional de zinco: comparação entre os teores de zinco no cabelo e fosfatase alcalina sérica em pré-escolares do município de João Pessoa, Paraíba}

Sandra Cristina da Silva-Santana 1 Alcides da Silva Diniz Margarida Maria de Feitas Lóla 3 Rejane Santana de Oliveira 4 Solange Maria Miranda Silva 5 Severino Francisco de Oliveira 6 Patrick Kolsteren 7

1.2 Departamento de Nutrição. Centro de Ciências da Saúde da Universidade Federal de Pernambuco. Av. Professor Morais Rego, s. n. Recife, PE, Brasil. CEP: 50.670-901.

3-6 Departamento de Nutrição. Enfermagem e Química, Centro de Ciências da Saúde, Universidade Federal da Paraíba. Campus I 7 Nutrition Unit. Prince Leopold Institute of Tropical Medicine. Antwerp, Belgium

\begin{abstract}
Objectives: to evaluate the nutritional status of zinc in children from two to five years old, institutionalised in daycare centers in the Municipality of João Pessoa, Paraíba.

Methods: a systematic random sample comprised of 377 children. The nutritional status of zinc was evaluated according to the following parameters: mineral concentrations in the hair and enzymatic activity levels of serum alkaline phosphatase.

Results: inadequate zinc concentrations prevalence in the hair was of $61,9 \%$ with predominance in the form of severe deficiency, 38,5\%. Prevalence of inadequate concentrations of levels of serum alkaline phosphatase activity was $40,1 \%$. Zinc concentrations in the hair did not correlatated with serum alkaline phosphatase ( $r=0,01 ; p=0,882)$. According to sex and age zinc distribution in the hair was homogenous. The alkaline phosphaase had identical behavior.

Conclusions: zinc deficiency is extremely high in the municipality of João Pessoa.
\end{abstract}

Key words Zinc, Nutritional status, Alkaline phosphatase, Child, preschool

\section{Resumo}

Objetivos: avaliar o estado nutricional de zinco em crianças de dois a cinco de idade, institucionalizadas em creches do município de João Pessoa, Paraíba.

Métodos: Utilizou-se uma amostra aleatória sistemática, constituída de 377 crianças. O status nutricional de zinco foi avaliado pelos seguintes parâmetros: concentrações do mineral no cabelo e níveis de atividade enzimática da fosfatase alcalina sérica.

Resultados: a prevalência das concentrações inadequadas de zinco no cabelo foi de 61,9\% predominando a deficiência na sua forma grave, $38,5 \%$. A prevalência das concentrações inadequadas de níveis de atividade enzimática da fosfatase alcalina sérica foi de 40,1\%. As concentrações de zinco no cabelo não mostraram correlação com a fosfatase alcalina sérica $(r=0,01 ; p=0,882)$. A distribuição do zinco no cabelo segundo sexo e idade foi homogênea; comportamento idêntico foi observado com a fosfatase alcalina.

Conclusões: a deficiência de zinco mostrou-se extremamente elevada no município de João Pessoa. Palavras-chave Zinco, Avaliação nutricional, Fosfatase alcalina, Pré-escolar 


\section{Introduction}

Trace elements deficiency also called hidden hunger is a plague affecting major segments of the developing countries population, specially excluded groups living in the outskirts of large urban centers, and that is true for developed countries as well. Zinc deficiency has, up to now, been regarded as a specific nutritional deficiency of relative value, if one considers the context of more prevailing nutritional deficiencies such as iron, iodine and Vitamin A. ${ }^{1}$

The essential need of zinc in human nutrition was demonstrated with the discovery of metabolic processes in which this mineral acts as an enzymatic co-factor. Currently zinc's participation as a component of over 200 metaloenzymes in human and animal tissues and as a structural component of various proteins, hormones and nucleotides is recognized.2,3 The adult human body possesses approximately 1,5 to $2 \mathrm{gr}$ of zinc, of which $80 \%$ is found in bones, muscles, liver, skin, ocular retina, hair and nails. It is equally found in the pancreas, kidneys and other body tissues and fluids such as prostate and sperm. In the blood, approximately $80 \%$ of zinc is found in erythrocytes, $16 \%$ in the plasma principally connected to albumin. Normal plasmatic concentration is around $100 \mu \mathrm{g} / \mathrm{dL} .4$

The first thing that happens in the presence of zinc deficiency is that the body uses zinc reserves and prolonged deficiency causes anorexia, growth retardation, delay in skeletal and sexual maturity, glucose intolerance, hypogonadism, dysfunction of the cell immune answer, hypogeusia, taste alterations, diarrhea, dermatitis and alopecia.5.6

Zinc concentration in hair, plasma, blood cells and urine excreted is reduced in the presence of severe deficiency. Another form of determining zinc deficiency is through the analysis of metaloenzymes activity, such as alkaline phosphatase, carbonic anhydrase and carboxipeptidase. ${ }^{7}$

The first clinical evidence in human zinc deficiency was described in 1940 in malnourished adults in China. Three decades after, primary zinc deficiency was demonstrated by Prasad et al. 8 and Halstead et al. 9 when they studied an adolescent population of the rural area in Iran and Egypt characterized by low stature, hypogonadism, mild anemia and low plasmatic zinc levels. In subsequent decades, zinc deficiency has been reported in various countries although its cartography is still not well defined not only in terms of space distribution but in terms of magnitude as well. It is estimated that this deficiency should be potentially considered as a public health issue in a number of developing countries. ${ }^{10,11}$
In Brazil, particularly in the Northeast, characterized as the poorest region in the country, there are no population based information on the prevalence of zinc deficiency in the potentially at risk group. There still is an important gap that should be filled for trace elements cartography components, not only in the Northeast but also in the country as a whole. Therefore, zinc deficiency determination in preschoolers will contribute to a better understanding of the problem, and can be used as a reference base to evaluate future interventions.

\section{Methods}

\section{Study's design}

A cross-sectional study was performed involving children from two to five years old, of low social and economic level, of both sexes, institutionalized in 24 public daycare facilities in the municipality of João Pessoa, Paraíba, Brazil, in the period of June to August 1998.

\section{Sample}

The sample was calculated based on a prevalence estimate of $13 \%$ of zinc deficiency in the Southeast region according to zinc's plasmatic concentrations. 12 An accuracy of $3 \%$ prevalence estimate and a reliability of $95 \%$ were adopted. Sample's size was of 377 children. Children were selected randomly according to systematic sample technique. 13

\section{Selection criteria}

Parents and caretakers received detailed information on the research for the obtainment of verbal and written consents for participation according to the established rules. Children who were on vitamins and/or minerals 30 days prior to data collection were excluded, as well as children whose consent was not obtained in writing from parents or caretakers, a requirement to participate of the research. Children when included in the study were submitted to a prescheduled agenda for different identification phases, such as blood collection (levels of enzymatic alkaline phosphatase ) as well as for the collection of hair samples (zinc in hair content).

\section{Laboratory analysis}

\section{Zinc: direct method - hair concentrations}

\section{Samples collection}

The samples were collected on the field by researchers of the Centro de Investigação em Micronu- 
trientes da Universidade Federal da Paraíba (UFPB). Twenty to $30 \mathrm{mg}$ of hair were collected using a stainless steel pair of scissors (surgical) from the central occipital region. Hair samples were stored in previously tagged airtight plastic recipients. Following that the samples were put in separate packets and stored for future processing and analysis.

\section{Processing}

The samples were washed with non-ionic detergent (Triton 0/00\%, VETEC) for 30 minutes under agitation and rinsed five times with de-ionized water. After one night (approximately 12 hours), placed in the oven for drying and then approximately $5 \mathrm{mg}$ of each hair sample was weighed and transferred to an Erlenmeyer. Following, $0,1 \mathrm{ml}$ of nitric acid $\left[\mathrm{HNO}_{3}\right.$ $(6 \mathrm{~N})]$ was added and the samples incubated at $80{ }^{\circ} \mathrm{C}$ in the oven for 12 hours for digestion process. The ashes obtained were then dissolved in de-ionized water and taken to an atomic absorption spectrophotometer for reading. 14

\section{Analysis}

Zinc in hair concentrations were determined by the atomic absorption spetrophotometry method with the use of a GBC-908 AA (GBC Scientific Equipament PTY LTD) 7 in the Laboratory of the Chemistry Department of the Federal University of Paraíba. The zinc rate was measured in $\mu \mathrm{mol} / \mathrm{g}$ of hair and concentrations under $1,68 \mu \mathrm{mol}$ per gram of hair were considered deficient. ${ }^{15}$ Severe deficiencies were determined by values under $1,1 \mu \mathrm{mol}$ per gram of hair, moderate deficiencies were determined by values between 1,1 e $1,51 \mu \mathrm{mol} / \mathrm{g}$ of hair and mild deficiencies by levels between 1,51 and $1,68 \mu \mathrm{mol} / \mathrm{g}$ gram of hair.

\section{Indirect method - Enzymatic activity of serum al- kaline phosphatase}

\section{Samples collection}

The samples were collected in daycare facilities by researchers of the Centro de Investigação da Universidade Federal da Paraíba. One $\mathrm{ml}$ of blood was collected by cubital venous puncture in the morning following a ten hour fast. Then the samples was centrifuged at $3.000 \mathrm{rpm}$ for ten minutes, separated and stored in a haemolysis tube free of trace elements. The samples were conserved at a temperature of $4 \mathrm{oC}$ for posterior analysis.

\section{Processing}

To measure alkaline phosphatase activity approximately $7 \mu$ of serum and $104 \mu$ l of alkaline phosphatase reagents were stored in a receptacle where they interacted at a de $37 \mathrm{o}^{\circ}$ temperature.

\section{Analysis}

The measure of alkaline phosphatase enzymatic activity was determined by spectrophotometer, with a wavelength of 405-510nm kinetic dichromatic technique used and Cobas Mira Plus equipment with direct automated reading. 16 Analysis was performed by the Laboratório de Análises Clínicas do Hospital Universitário Lauro Wanderley of UFPB. Enzymatic activity of alkaline phosphatase was measured in Unit Litter (U/L) with values under 250U/L. 17 considered enzymatic activity deficient.

\section{Statistical analysis}

Variance homogeneity was evaluated by the Levene test. Variables such as normal distribution and homogenous variables had their median compared by the $t$ Student's tests (two variables) and through variance analysis (> two variables), with the use of the Scheffé test ${ }^{13}$ as the a posteriori test. Enzymatic activity distribution of alkaline phosphatase did not comprise with paramedic criteria and was described by the median and inter-quartile interval (Percentiles 25 and 75, respectively). Mann Whytney non-parametric tests were employed to compare the medians (two variables) and of Kruskal-Wallis (> two variables). The association between continuous variables was tested by the Pearson correlation. In the descriptive analysis of proportions a binomial distribution to the normal distribution was approximated with a confidence interval of $95 \%$. Sample's homogeneity tested according to the variables studies was verified through the $\chi^{2}$ homogeneity test. Significance level of $5 \%$ for variables normality criteria and nullity hypothesis rejection. Databank organization was performed by the Epi-info, version 6.02 software. 18 Statistical calculations were processed by SPSS (Statistical Package for Social Science). 19

The Ethics Committee of the Prince Leopold Institute of Tropical Medicine, Antwerp, Belgium and the Hospital Universitário Lauro Wanderley of the Universidade Federal da Paraíba approved the research project based on international norms of research in humans.

\section{Results}

The prevalence of inadequate rates of zinc in hair $(<$ $1,68 \mu \mathrm{mol} / \mathrm{g}$ ) was of $61,9 \%$. Data indicate that severe deficiency $(<1,1 \mu \mathrm{mol} / \mathrm{g})$ was significantly higher than moderate $(1,1-1,51 \mu \mathrm{mol} / \mathrm{g})$, and this higher than mild deficiency $(1,51-1,68 \mu \mathrm{mol} / \mathrm{g})$ (Table 1$)$. 
Distribution of zinc concentration in hair in children from two to five years old in daycare facilities. João Pessoa, PB, Brasil, 1998.

\begin{tabular}{lrrr}
\hline Zinc concentrations in hair $(\mu \mathrm{mol} / \mathbf{g})^{*}$ & $\mathbf{n}$ & $\%$ & $\mathbf{9 5 \%} \mathrm{Cl}$ \\
\hline$<1,10$ & 145 & 38,5 & $33,6-43,6$ \\
$1,10 \vdash 1,51$ & 70 & 18,6 & $14,8-22,9$ \\
$1,51-1,68$ & 18 & 4,8 & $2,9-7,6$ \\
$\geq 1,68$ & 144 & 38,1 & $33,3-43,3$ \\
Total & 377 & 100,0 & \\
\hline
\end{tabular}

*Values in $\log 10, \chi^{2}=16,5, g l=3 ; p=0,001$

Serum alkaline phosphatase low activity prevalence $(<250 \mathrm{U} / \mathrm{L})$ points towards a significant deficiency of enzymatic activity which could indirectly reflect a pronounced zinc deficiency in the body (Table 2).
A homogenous distributive behavior of zinc in hair concentrations distribution was determined $(\mathrm{p}=$ 0,709 ) related to the sex variable (Table 3 ).

Table 2

Distribution of enzymatic serum alkaline phosphatase in children from two to five years old in day care facilities. João Pessoa, PB, Brazil, 1998.

\begin{tabular}{|c|c|c|c|}
\hline Levels of activity of serum alkaline phosphatase (U/L & $\mathbf{n}$ & $\%$ & $95 \% \mathrm{Cl}$ \\
\hline$<250$ & 151 & 40,1 & $35,1-45,2$ \\
\hline$\geq 250$ & 226 & 59,9 & $54,8-64,9$ \\
\hline Total & 377 & 100,0 & \\
\hline
\end{tabular}

$\chi^{2}=13,6, g l=1, p=0,001$ 
Distribution of zinc concentrations in hair and serum phosphatase enzymatic activity, according to sex in children from two to five years old in day care facilities. João Pessoa, PB, Brazil, 1998.

\begin{tabular}{|c|c|c|c|c|c|c|}
\hline \multirow{2}{*}{ Sex } & \multicolumn{3}{|c|}{ Zinc concentrations in hair * $(\mu \mathrm{mol} / \mathrm{g}) * *$} & \multicolumn{3}{|c|}{ Levels of serum alkaline phosphatase activity $(\mathrm{U} / \mathrm{L}) * * *$} \\
\hline & $\mathrm{n}$ & Average & $\mathrm{DP}$ & $\mathrm{n}$ & Median & Quartiles $25-75$ \\
\hline Male & 187 & 0,2 & 0,3 & 187 & 264,0 & $221,0-310,0$ \\
\hline Female & 190 & 0,2 & 0,3 & 190 & 274,5 & $229,8-325,0$ \\
\hline Total & 377 & 0,2 & 0,3 & 377 & 269,0 & $227,0-319,0$ \\
\hline
\end{tabular}

*Values in Log10, ** Tested t de Student $=0,7, p=0,709, * * *$ Mann Whitney $U \mathrm{Z}=-1,3, p=0,199$

The distribution of zinc in hair according to child's age was homogenous $(p=0,874)$ The average zinc in hair concentration did not vary according to age group characterized in 12 months class intervals (Table 4).

\section{Table 4}

Distribution of zinc concentrations in hair and levels of serum alkaline enzymatic activity, according to age in children from two to five years old, in daycare facilities. João PB, Brazil, 1998.

\begin{tabular}{|c|c|c|c|c|c|c|}
\hline \multirow{2}{*}{ Age (months) } & \multicolumn{3}{|c|}{ Zinc concentrations in hair* $(\mu \mathrm{mol} / \mathrm{g})^{* *}$} & \multicolumn{3}{|c|}{ Levels of serum alkaline phosphatase activity $(\mathrm{U} / \mathrm{L}) * * *$} \\
\hline & $\mathrm{n}$ & Average & $\mathrm{DP}$ & $\mathrm{n}$ & Median & Quartiles 25 - 75 \\
\hline $24 \vdash 36$ & 48 & 0,2 & 0,4 & 48 & 266,5 & $209,0-310,0$ \\
\hline $36 \vdash 48$ & 115 & 0,2 & 0,4 & 115 & 275,0 & $327,0-327,0$ \\
\hline $48 \vdash 60$ & 214 & 0,2 & 0,3 & 214 & 266,5 & $229,0-312,0$ \\
\hline Total & 377 & 0,2 & 0,4 & 377 & 269,0 & $227,0-318,0$ \\
\hline
\end{tabular}

*Values in Log10, ** ANOVA $\left.\mathrm{F}_{2,374}\right)=0,1, \mathrm{p}=0,874, * * *$ Kruskal-Wallis $\chi^{2}=0,7, \mathrm{p}=0,709$ 
Enzymatic activity of alkaline phosphatase did not vary with sex $(p=0,199)$. Although the levels of enzymatic activity of serum alkaline phosphatase point towards lower median values for male children, this trend was not statistically validated (Table $3)$. On the other hand, alkaline phosphatase enzymatic activity did not show any relation with the age variable $(p=0,709)$. Although the distribution of the levels of serum alkaline phosphatase enzymatic activity signals towards median values for children between 24 and 36 months old and higher for children between 36 and 48 months old, this difference like in the sex distribution example was not statistically confirmed ( $p=0,709)$ (Table 4). The association test between zinc in hair concentrations and the levels of enzymatic activity of alkaline phosphatase did not show correlation between the two variables $(r=$ $0,01 ; \mathrm{p}=0,882)$.

\section{Discussion}

Trace elements deficiency has been the focus of increasing attention among researchers, formulators and managers of health and nutrition policies due to its ample spatial distribution, magnitude and damages to health. Zinc deficiency although until recently was not as visible when compared to the relevance granted by international institutions and organizations to iron, iodine and Vitamin A deficiencies, has increasingly been gaining more attention within the scenario of nutritional epidemiology.

There is no available information for the Northeast Brazil region on the magnitude and distribution of zinc deficiency. Therefore, the João Pessoa municipality results, where the prevalence of hair in zinc deficiency in children from two to five years was extremely high, is a fact calling for concern and thought. It should be highlighted that the majority had the deficiency in its more severe form.

These findings are corroborated by data from the other indicator of the zinc nutritional status, the levels of enzymatic activity of serum alkaline phosphatase where the prevalence of inadequate concentrations of this enzyme was shown to be equally high. Therefore, the adoption of an effective intervention program for the prevention and control of this nutritional deficiency is of fundamental value. The population, object of this study, is of low social and economic level, living in the outskirts of the city in precarious health and hygiene conditions favoring the proliferation of diseases and consequently contributing to increase child morbidity and mortality.

Zinc deficiency has been noted in other Brazil- ian regions. In the Southeast, Favaro and Vannucchi 12 demonstrated that around $13 \%$ of the children from two to seven years old of low social and economic levels and living in Ribeirão Preto, State of São Paulo, had zinc plasmatic concentrations considered deficient $(<10,7 \mu \mathrm{mol} / \mathrm{L})$. Studies performed in Rio de Janeiro by Donangelo e Azevedo 20 and in Manaus by Rocha et al. as quoted by Favaro and Vannucchi 12 found deficient zinc values in children specially the ones with energetic-protein malnutrition.

Data of children living in urban Brasilia who had their dairy diets submitted to chemical analysis indicated insufficient zinc intake in bottle fed children, at least in the first six months of life. 21

On a World level, zinc deficiency has been reported in populations living in unfavorable social and economic contexts. Data from Indonesia indicate that $25 \%$ of the mothers and $17 \%$ of their children had zinc deficiency. 22 On the other turn, Vietnamese pre-schoolers had $36,3 \%$ of zinc plasmatic concentrations which, are considered insufficient $(<$ $10,7 \mu \mathrm{mol} / \mathrm{L}) .23$

Analysis of zinc in hair concentrations and of serum alkaline phosphatase activity according to the sex variable indicated that this variable was not a discriminating factor as per the indicators studies, this is a finding of other authors as well related to zinc in hair concentrations .12,24 On the other hand O'Leary et al. ${ }^{25}$ found an association between zinc in hair concentrations and the sex variable in preschoolers of low social and economic levels living in rural Costa Rica. Authors further reported that female children had significantly higher contents of zinc in hair than male children. The higher vulnerability of male children to trace element deficiencies, especially iron and Vitamin A has been reported in different contexts. 26,27

The scarcity of data allowing for the assessment of the association between enzymatic activity of alkaline phosphatase and sex, age, weight and height variables in children from two to five years old, the age group studied, demonstrates that this is a theme with a very low priority in the specialized literature and this work aims to contribute to reduce this gap furnishing relevant data for the better understanding of the problem. It should be emphasized, nevertheless, that although the level of enzymatic activity of alkaline phosphatase does not indicate significant differences related to sex, distribution of enzymatic activity of alkaline phosphatase medians pointed towards lower values for male children.

The disagreement related to parameters and indicators used to evaluate zinc nutritional status is con- 
siderable. The absence of association of concentrations of zinc in hair and serum enzymatic activity of alkaline phosphatase observed in this study favors some questions, considering they did not follow the expected trend.

This could be explained by the fact that the indicators in question reflected marginal stages of deficiency in different biological moments. Therefore, zinc in hair concentrations would be the more adequate indicator to evaluate chronic zinc deficiency because it primarily reflects the changes of zinc intake for long periods, 28 on the other hand, the levels of enzymatic activity of alkaline phosphatase would only reveal the actual status of zinc deficiency in the body, reflecting an insufficient consumption of this trace element in the present.26,29 It should be pointed out that the levels of enzymatic activity of serum alkaline phosphatase can suffer considerable variations dependent on pathological changes in the body, the example of this would be digestive and bone con-

\section{Acknowledgements}

To the Institute Prince Leopold for Tropical Medicine, Belgium and the Ministério da Saúde do Brasil, for the technical and financial support in the accomplishment in this study.

\section{References}

1. FAO (Food and Agriculture Organization), OMS (Organisation Mondiale de la Santé). Nutrition et développement une evaluation d'ensemble: Conférence Internationale sur la Nutrition. Rome: FAO;OMS; 1992.

2. Guthrie HA, Picciano MF. Human nutrition. St Louis: Mosby; 1995.

3. Cozzolino SMF. Biodisponibilidade de minerais. Rev Nutr [Campinas]1998; 10: 87-98.

4. Cousins RJ. Zinc. In: Ziegler EE, Filer LJ. Conocimientos actuales sobre nutrición. 7. ed. Washington, DC: Organización Panamericana de la Salud (OPS); 1997. p. 31227.

5. WHO (World Health Organization). Zinc. In: WHO. Trace elements in human nutrition and health. Geneva: WHO; 1996.

6. Fernandez H, Estévez AI. Función del cinc en la recuperación imunonutricional de lactantes malnutridos. Rev ditions.

Studies have demonstrated a positive correlation between zinc serum concentrations and levels of enzymatic activity of alkaline phosphatase.7,30 It has further been reported that the serial determination of plasmatic zinc and enzymatic activity of serum alkaline phosphatase during repletion could be a valid tool for diagnosing moderate and severe zinc deficiencies as well as for diagnose exclusion.7,30 In a last analysis the conjunction of indicators increases the degree of diagnostic accuracy for it amplifies the spectre of detection in different stages of the mineral deficiency. Therefore, diagnostic methods enabling inferences of this order are extremely advisable. Another aspect deserving consideration, relates to the impossibility of eliminating the concurrent simultaneous deficiency of other trace elements, examples of which are iron and Vitamin A, which in principle could be concurrently acting in determining the deficiency status.
Cubana Aliment Nutr 2000; 14: 65-70.

7. Gibson RS. Zinc nutrition in developing countries. Nutr Res Rev 1994; 7: 151-73.

8. Prasad AS, Halstead JA, Nadimi M. Syndrome of iron deficiency anemia, hepatosplenomegaly, hypogonadism, dwarfism and geofagia. Am J Med 1961; 31: 532-46.

9. Halstead JA, Ronaghy HA, Abadi P. Zinc deficiency in man: the Shiraz experiment. Am J Med 1972: 53: 277-84

10. Sandstead HH, Penland JG, Alcock NW, Dayal HH, Chen XC, LI JS. Effects of repletion with zinc and other micronutrients on neuropsychologic performance and growth of Chinese children. Am J Clin Nutr 1998; 68 Suppl: 470S-5S.

11. Fisberg M, Fernandes RL, Mittermeyer O, Rhein SO. Deficiência de zinco em pediatria. Nutr Pauta 2001; 7: 50-6.

12. Favaro RMD, Vannucchi H. Níveis plasmáticos de zinco e antropometria de crianças de periferia de centro urbano 
no Brasil. Rev Saúde Pública 1990; 24: 5-10.

13. Berquó ES, Souza JMP, Gotlieb SLD. Bioestatística. São Paulo: EPU, 1981.

14. Harrison WW, Yurachek JP, Benson CA. The determination of trace elements in human hair by atomic absorption spectroscopy. Clin Chim Acta 1969; 23: 83-91.

15. Cavan KR, Gibson RS, Grazioso CF, Isague AM, Ruz M, Solomons NW. Growth and body composition of periurban Guatemalan children in relation to zinc status: a longitudinal zinc intervention trial. Am J Clin Nutr 1993; 57: 344-52.

16. Hausamen TU, Helger R, Rick W. Optimal conditions for the determination of serum alkaline phosphatase by a new kinetic method. Clin Chim Acta 1967; 15: 214-5.

17. Walravens PA, Krebs NF, Hambidge KM. Linear growth of low-income preschool children receiving a zinc. Am J Clin Nutr 1983; 38 Suppl: 195-201

18. Dean J. Epi-info [computer program]. Version 6.02. Atlanta: Centers for Disease Control and Prevention (CDC); 1994.

19. SPSS (Statistical Package for Social Science). [computer program].Version 10.1. Chicago; 1999.

20. Donangelo CM, Azevedo CE. Zinco sérico em crianças brasileiras de famílias de baixa renda. Arch Latinoam Nutr 1984; 34: 290-7.

21. Dórea J. Zinc in urban infants and children from Brasilia. Arch Latinoam Nutr 1997; 47 (2 Suppl 1): 39-40.

22. Dijkhuizen MA, Wieringa FT, West CE, Muherdiyantiningsih $\mathrm{M}$. Concurrent micronutrient deficiencies in lactating mothers and their infants in Indonesia. Am J Clin
Nutr 2001; 73: 786-91.

23. Thu BD, Schultink W, Dillon D, Gross R, Leswara ND, Khoi HH. Effect of daily and weekly micronutrient supplementation on micronutrient deficiencies and growth in young Vietnamese children. Am J Clin Nutr 1999; 69: 80-6.

24. Sturaro A, Parvoli G, Doretti L. The influence of color, age and sex on the content of zinc, copper, nickel, manganese and lead in human hair. Bio Trace Elem 1994; 40 1-8.

25. O' Leary MJ, Mata LJ, Hegarty PVJ. Hair zinc levels in rural Costa Rican infants and preschool children. Am J Clin Nutr 1980; 33: 2194-7.

26. Sommer A, West KPJR. Vitamin A deficiency: health, survival and vision. New York: Oxford University; 1996

27. Diniz AS. Aspectos clínicos, subclínicos e epidemiológicos da hipovitaminose A no Estado da Paraíba [tese doutorado]. Recife: Departamento de Nutrição, Centro de Ciências da Saúde da Universidade Federal de Pernambuco; 1997.

28. Kolsteren PW, Rahman SR, Hilderbrand K, Diniz AS. Treatment for iron deficiency anemia with a combined supplementation of iron, vitamin A and zinc in women of Dinajpur, Bangladesh. Eur J Clin Nutr 1999; 53: 102

29. Xue-Cun C, Tai-Na Y, Yin-Sheng H, Qiuyan M, Zhi-Min $\mathrm{H}$, Li- Xiang Li. Low levels of zinc in hair and blood, pica, anorexia and poor growth in Chinese preschool children. Am J Clin Nutr 1985; 42: 694-700.

30. Weissmann K, Hoyer H. Serum alkaline phosphatase activity in acrodermatitis enteropathica: an index of the serum zinc level. Acta Dermatol 1979; 59: 89-90.

Submitted on Jun 3, 2002

Final version re-submitted in Augost 2, 2002

Approved on October 3, 2002 